\title{
ANALISIS TINGKAT EFISIENSI BELANJA LANGSUNG PADA SEKRETARIAT DAERAH KOTA TOMOHON
}

\author{
Ireyne R. Gerung ${ }^{1}$, Lintje Kalangi ${ }^{2}$, Rudy J. Pusung ${ }^{2}$ \\ ${ }^{1,2}$ Jurusan Akuntansi, Fakultas Ekonomi dan Bisnis, Universitas Sam Ratulangi, Jl. Kampus Bahu, Manado, \\ 95115, Indonesia \\ ${ }^{1}$ E-mail: ireynegerung@yahoo.com
}

\begin{abstract}
Budget is important to help all activities carried out in the company or agency. The purpose of this study is to know the level of direct spending management efficiency. The method of this study is a qualitative with descriptive method. The results show that the efficiency levels are excellent. The level of efficiency in the year 2016 with a efficiency rate of 65.04\%, year 2017 with a efficiency rate of $65.14 \%$ and year 2018 with a efficiency rate of $67.31 \%$. On year of 2016 to 2018 as overall its efficiency level is in efficient category which means there is a good managing for existing budgets with minimum budget usage for maximum results.
\end{abstract}

Keywords: analysis; budget; efficiency; direct spending; managing

\section{PENDAHULUAN}

Penganggaran merupakan bagian terpenting dari pengelolaan keuangan pemerintahan dan dapat dijelaskan dari berbagai perspektif, seperti politik, ekonomi, keuangan, dan akuntansi (Abdullah, 2015:3). Dalam Nota Keuangan dan Rencana Anggaran Pendapatan dan Belanja Negara (RAPBN) tahun 2011 disebutkan bahwa daya serap anggaran belanja kementerian dan lembaga dalam lima tahun terakhir rata-rata hanya $90 \%$ dari pagu anggaran yang ditetapkan dalam APBN setiap tahun. Penyerapan anggaran merupakan salah satu tahapan dari siklus anggaran yang dimulai dari perencanaan anggaran, penetapan dan pengesahan anggaran oleh Dewan Perwakilan Rakyat (DPR) dimana tahapan penyerapan anggaran ini dimulai ketika Undang-Undang (UU) Anggaran Pendapatan dan Belanja Negara (APBN) disahkan oleh DPR (Kuncoro, 2013:7).

Sasongko dan Parulian (2015:2) berpendapat bahwa anggaran adalah rencana kegiatan yang akan dijalankan oleh manajemen dalam satu periode yang tertuang secara kuantitatif dimana informasi yang dapat diperoleh dari anggaran di antaranya jumlah produk dan harga jualnya untuk tahun depan. Hal ini mengartikan bahwa secara umum anggaran merupakan suatu rencana kerja yang disusun secara sistematis yang dinyatakan dalam satuan uang, barang atau jasa untuk waktu periode yang akan datang. Keuangan daerah yang dinyatakan dalam bentuk anggaran merupakan suatu rencana operasional keuangan daerah, dimana di satu sisi menggambarkan penerimaan pendapatan daerah, dan di lain sisi menggambarkan pengeluaran untuk membiayai pengeluaran rutin dan pengeluaran pembangunan daerah dalam satu tahun anggaran. Pada kedua sisi anggaran tersebut, sisi pengeluaran cenderung menjadi pusat perhatian publik karena terkait dengan kinerja pemerintah dalam memberikan pelayanan kepada masyarakat.

Berdasarkan penyajian laporan keuangan pemerintah daerah, sisi pengeluaran daerah atau belanja daerah terdiri atas belanja operasi, belanja modal, belanja tak terduga, dan belanja transfer. Pengklasifikasian jenis-jenis belanja ini sesuai dengan yang diamanatkan dalam Peraturan Pemerintah Nomor 71 Tahun 2010 tentang Standar Akuntansi Pemerintahan. Dalam pelaksanaan belanja tersebut, pemerintah daerah diwajibkan untuk mengelola anggarannya berdasarkan asas efektivitas, efisiensi, transparansi, dan akuntabilitas 
sebagaimana yang telah diamanatkan dalam Pasal 280 ayat (2) Undang-Undang Nomor 23 Tahun 2014 tentang Pemerintahan Daerah.

Rendahnya penyerapan anggaran mengindikasikan kinerja pemerintah belum efektif dalam merealisasikan anggaran, sehingga beberapa program kerjanya tidak bisa didanai. Selain itu, Tjahjo Kumolo selaku Menteri Dalam Negeri juga menyatakan bahwa mayoritas pemerintah daerah masih lebih banyak menggunakan anggarannya untuk menggaji pegawai ketimbang membelanjakannya untuk proyek pembangunan, sehingga menunjukkan kinerja yang tidak efisien (Kontan, 2016). Rendahnya daya serap anggaran setiap tahun menjadi masalah rutin setiap tahunnya. Penyelenggaraan pemerintah daerah tidak lepas dari adanya penggunaan dan pemanfaatan anggaran serta pendapatan daerah. Dan setiap tahun juga selalu saja pemerintah daerah mempersiapkan perencanaan anggaran atau yang sering disebut dengan Anggaran Pendapatan dan Belanja Daerah. Karena anggaran pemerintah terkait dengan penentuan jumlah alokasi dana untuk setiap program dan aktivitas yang meggunakan dana milik masyarakat.

Anggaran merupakan alat perencanaan target yang harus dicapai oleh pemerintah, serta sebagai alat untuk pengendalian alokasi sumber dana publik yang disetujui oleh legislatif untuk nanti dibelanjakan. Pada umumnya dalam organisasi sektor publik akan dinilai baik jika yang bersangkutan mampu dalam melaksanakan tugas dalam mencapai tujuan yang telah ditetapkan pada standar yang tinggi dengan biaya yang rendah. Tuntutan baru untuk organisasi sektor publik yaitu selalu memperhatikan value for money. Karena tujuan yang dikehendaki masyarakat selalu mencakup pertanggungjawaban mengenai pelaksanaan value for money, yaitu dalam pengadaan dan alokasi sumber daya, efisien (berdaya guna) dalam penggunaan sumber daya dalam arti penggunaannya diminimalkan dan hasil dimaksimalkan (maximizing benefits and minimizing cost), serta (berhasil guna) dalam arti mencapai sasaran.

Pada instansi pemerintahan lainnya anggaran merupakan sesuatu yang penting untuk membantu segala aktivitas yang dilakukan dalam perusahaan atau instansi tersebut, begitu pula dengan Sekretariat Daerah Kota Tomohon yang diharapkan anggaran yang ada dapat membantu serta mempermudah semua aktivitas yang ada. Adapun permasalahan terkait dengan pelaksanaan anggaran belanja langsung pada Sekretariat Daerah Kota Tomohon diantaranya yaitu kurangnya daya serap anggaran serta perbedaan jumlah anggaran yang diterima setiap tahunnya yang berdampak terhadap proses perealisasian anggaran pada Sekretariat Daerah Kota Tomohon.

\section{TINJAUAN PUSTAKA}

Akuntansi pemerintahan adalah akuntansi yang bersangkutan dengan bidang keuangan negara dari anggaran sampai pelaksanaan dan pelaporan termasuk pengaruh yang ditimbulkan (Sujarweni, 2015:18). Akuntansi pemerintah termasuk juga lembaga-lembaga non profit mengkhususkan pada masalah dan pelaporan transaksi dari unit-unit pemerintah dan organisasi non profit lainnya. Fungsi akuntansi pemerintah adalah menyediakan laporan akuntansi yang bermanfaat mengenai aspek kepengurusan administrasi pemerintah, serta membantu manajemen dalam melaksanakan pengawasan atas pelaksanaan anggaran sesuai dengan ketentuan undang-undang yang berlaku (Sadeli, 2015:6). Akuntansi pemerintahan mempunyai beberapa tujuan yaitu: (1) tujuan pertanggungjawaban, dimana pemerintah harus memberikan informasi keuangan secara lengkap, memberikan informasi keuangan secara cermat, dalam bentuk dan waktu yang tepat; (2) tujuan manajerial, dimana informasi keuangan digunakan untuk perencanaan, penganggaran, pelaksanaan, pemantauan, pengendalian anggaran, perumusan kebijakan, pengambilan keputusan, dan penilaian kinerja pemerintah adalah tujuan yang diharapkan dapat dicapai dengan adanya akuntansi pemerintah; dan (3) tujuan pengawasan, dimana informasi yang dihasilkan akuntansi 
pemerintahan harus memungkinkan terselenggaranya pemeriksaan oleh aparat pengawas (Nordiawan, 2009:10).

Akuntansi keuangan daerah atau akuntansi sektor publik adalah proses pengidentifikasikan, pengukuran, pencatatan, dan pelaporan transaksi keuangan dari entitas pemerintah daerah dalam rangka pengambilan keputusan ekonomi yang diperlukan oleh pihak eksternal (Ratmono, 2015:15). Akuntansi sektor publik adalah akuntansi yang digunakan untuk mencatat peristiwa ekonomi pada organisasi non profit atau nirlaba. Secara sederhana, akuntansi sektor publik ini banyak dipakai oleh organisasi sektor publik, seperti partai politik, masjid, puskesmas, rumah sakit, sekolah, atau universitas, lembaga swadaya masyarakat, dan pemerintah pusat (Erlina, 2015:15).

Akuntansi sektor publik sering diartikan sebagai akuntansi dana masyarakat, yaitu teknik dan analisis akuntansi yang digunakan pada organisasi sektor publik. Akuntansi sektor publik memiliki kaitan erat dengan penerapan dan perlakuan akuntansi pada wilayah publik. Akuntansi sektor publik adalah mekanisme teknik dan analisis akuntansi yang diterapkan pada pengelolaan dana masyarakat di lembaga-lembaga tinggi negara dan departemendepartemen di bawahnya, pemerintah daerah, BUMN, BUMD, LSM, dan yayasan sosial pada proyek-proyek kerjasama sektor publik dan swasta (Bastian, 2010:3).

Akuntansi sektor publik berkaitan dengan tiga hal, yaitu persediaan informasi, pengendalian manajemen dan akuntabilitas. Akuntansi sektor publik ini merupakan alat informasi bagi pemerintah maupun alat informasi bagi publik. Informasi akuntansi ini sangat bermanfaat untuk pengambilan keputusan. Mardiasmo (2009:14) berpendapat bahwa tujuan akuntansi sektor publik adalah sebagai berikut:

1. Memberikan informasi yang diperlukan untuk mengelola secara tepat, efisien, dan ekonomis atas suatu operasi dan alokasi sumber daya yang dipercayakan kepada organisasi. Tujuan ini terkait dengan pengendalian manajemen (management control).

2. Memberikan informasi yang memungkinkan bagi manajer untuk melaporkan pelaksanaan tanggung jawab mengelola secara tepat dan efektif program dan penggunaan sumber daya yang menjadi wewenangnya, dan memungkinkan bagi pegawai pemerintah untuk melaporkan kepada publik atas hasil operasi pemerintah dan penggunaan dana publik. Tujuan ini terkait dengan akuntabilitas (accountability).

Anggaran merupakan suatu alat yang digunakan manajemen untuk menjalankan rencana-rencana atau target yang ingin dicapai oleh suatu organisasi. Anggaran merupakan suatu rencana yang disusun secara sistematis yang meliputi seluruh kegiatan perusahaan dalam jangka pendek yang dinyatakan dalam satuan unit kuantitatif. Anggaran digunakan sebagai alat atau sistem pengendalian manajemen yang sangat efektif dan efisien untuk mencapai tujuan organisasi baik di sektor swasta maupun di sektor publik (Wati, 2013). Anggaran merupakan alat perencanaan dan pengendalian. Perencanaan adalah pandangan ke depan untuk melihat tindakan apa yang seharusnya dilakukan agar dapat mewujudkan tujuantujan tertentu, sedangkan pengendalian adalah melihat ke belakang, memutuskan apa yang sebenarnya telah terjadi dan membandingkannya dengan hasil yang direncanakan sebelumnya (Rahayu, 2013:4). Anggaran yaitu suatu rencana yang disusun secara sistematis yang meliputi seluruh kegiatan perusahaan yang dinyatakan dalam unit kesatuan moneter yang berlaku untuk jangka waktu periode tertentu yang akan datang (Suharsimi, 2010:1). Anggaran (budget) merupakan rencana tertulis mengenai kegiatan suatu organisasi yang dinyatakan dalam suatu uang, tetapi dapat juga dinyatakan dalam satuan barang/jasa (Nafarin, 2013:11). Menurut Ekawarna et al. (2009), pemakaian anggaran dalam kegiatan organisasi swasta maupun pemerintah memiliki kelebihan dan kelemahan, kelebihan penggunaan anggaran adalah: (1) penyusunan anggaran merupakan kekuatan manajemen/pengelola dalam menyusun perencanaan, dimana manajemen/pengelola organisasi melihat ke depan untuk menentukan tujuan organisasi yang dinyatakan dalam ukuran finansial; (2) anggaran dapat 
digunakan sebagai alat koordinasi berbagai kegiatan organisasi; (3) implementasi anggaran dapat menciptakan alat untuk pengawasan kegiatan organisasi; (4) pengelola/manajer dapat memeriksa dengan seksama penggunaan sumber ekonomi yang dimiliki oleh organisasi, apakah sudah efektif dan efisien; (5) pemakaian anggaran mengakibatkan timbulnya kesadaran tentang pentingnya biaya sebelum dana disediakan; (6) pemakaian anggaran dapat mendorong dipakainya standar sebagai alat pengukur prestasi suatu bagian atau individu di dalam organisasi; dan (7) pemakaian anggaran dapat membantu manajemen/pengelola dalam pengambilan keputusan. Sedangkan kelemahan pemakaian anggaran adalah: (1) anggaran didasarkan pada estimasi atas kegiatan yang akan datang, ketepatan estimasi sangat tergantung kepada pengalaman dan kemampuan estimator, dan ketidaktepatan anggaran berakibat tidak dapat dipakainya anggaran sebagai alat perencanaan, koordinasi, dan pengawasan dengan baik; (2) anggaran harus disesuaikan dengan perubahan kondisi dan asumsi; (3) anggaran dapat dipakai sebagai alat oleh manajemen/pengelola organisasi apabila semua pihak secara terus menerus berusaha berkoordinasi dan bertanggung jawab atas tercapainya tujuan yang telah ditentukan didalam anggaran; dan (4) anggaran tidak dapat menggantikan fungsi manajemen/pengelola, tetapi anggaran oleh manajemen/organisasi perlu disadari sebagai alat untuk membantu manajemen/pengelola.

Istilah anggaran dalam bahasa Inggris dikenal dengan kata budget, berdasarkan National Committee on Governmental Accounting (NCGA) yang saat ini telah diubah menjadi Governmental Accounting Standards Board (GASB), definisi anggaran adalah rencana operasi keuangan yang mencakup estimasi pengeluaran yang diusulkan, dan sumber pendapatan yang diharapkan untuk membiayainya dalam periode waktu tertentu (Bastian, 2010:191). Anggaran adalah dokumen yang berisi estimasi kinerja, baik berupa penerimaan dan pengeluaran yang disajikan dalam ukuran moneter yang akan dicapai pada periode waktu tertentu dan menyertakan data masa lalu sebagai bentuk pengendalian dan penilaian kinerja (Halim, 2016:48). Anggaran adalah pernyataan mengenai estimasi kinerja yang hendak dicapai selama periode waktu tertentu yang dinyatakan dalam ukuran financial, sedangkan penganggaran adalah proses atau metode untuk mempersiapkan suatu anggaran (Mardiasmo, 2011:61).

National Committee on Governmental Accounting (NCGA) dalam Haruman (2010:11), mengemukakan bahwa anggaran sektor publik memiliki beberapa fungsi utama yaitu sebagai berikut: (1) anggaran merupakan hasil akhir proses penyusunan rencana kerja; (2) anggaran merupakan cetak biru aktivitas yang akan dilaksanakan dimasa mendatang; (3) anggaran sebagai alat komunikasi interen yang menghubungkan berbagai unit kerja dan mekanisme kerja antara atasan dan bawahan; (4) anggaran sebagai alat pengendali unit kerja; (5) anggaran merupakan alat motivasi dan persuasi tindakan efektif dan efisien dalam mencapai visi organisasi; (6) anggaran merupakan instrumen politik; dan (7) anggaran merupakan instrumen kebijakan fiskal. Menurut Ekawarna et al. (2009), tujuan anggaran pemerintah adalah untuk: (1) menyatakan harapan/sasaran pemerintah secara jelas dan formal, sehingga bisa menghindari kerancuan dan memberi arah terhadap apa yang hendak dicapai oleh pemerintah; (2) mengkomunikasikan harapan manajemen kepada pihak-pihak terkait sehingga anggaran mudah dimengerti, didukung, dan dilaksanakan; (3) menyediakan rencana terinci mengenai aktivitas dengan maksud mengurangi ketidakpastian dalam memberikan pengarahan yang jelas bagi individu dan kelompok dalam upaya mencapai tujuan; (4) mengkoordinasikan cara/metode yang akan ditempuh dalam rangka memaksimalkan sumber daya; dan (5) menyediakan alat pengukur dan mengendalikan kinerja individu dan kelompok, serta menyediakan informasi yang mendasari perlu tidaknya tindakan koreksi.

Standar Akuntansi Pemerintahan (SAP) menyatakan bahwa belanja diakui pada saat terjadinya pengeluaran dari Rekening Kas Umum Negara/Daerah. Definisi ini sejalan dengan 
Peraturan Menteri Dalam Negeri No. 13 Tahun 2006 sebagaimana telah diubah dengan Permendagri No. 59 Tahun 2007 dan adanya perubahan kedua dengan Peraturan Menteri Dalam Negeri No. 21 Tahun 2011 tentang perubahan kedua. Permendagri No 13 tahun 2006 pasal 4 ayat 1 tentang Azas Umum Pengelolaan Keuangan Daerah menyatakan bahwa keuangan daerah dikelola secara tertib, taat pada peraturan perundang-undangan, efektif, efisien, ekonomis, transparan, dan bertanggung jawab dengan memperhatikan azas keadilan, kepatuan, dan manfaat untuk masyarakat. Khusus konteks efisien dijelaskan lebih lanjut bahwa efisien merupakan pencapaian keluaran yang maksimum dengan masukan tertentu atau penggunaan masukan terendah untuk mencapai keluaran tertentu. Efisiensi merupakan tindakan memaksimalkan hasil dengan menggunakan modal (tenaga kerja, material dan alat) yang minimal (Stoner, 2010:19). Efisiensi merupakan rasio antara input dan output, serta perbandingan antara masukan dan pengeluaran. Apa saja yang dimaksudkan dengan masukan serta bagaimana angka perbandingan tersebut diperoleh akan tergantung dari tujuan penggunaan tolak ukur tersebut. Efisiensi berhubungan erat dengan konsep produktifitas. Pengukuran efisiensi dilakukan dengan menggunakan perbandingan antara output yang dihasilkan terhadap input yang digunakan (cost of output). Proses kegiatan operasional disebut efisien jika suatu produk atau hasil kerja tertentu dapat dicapai dengan penggunaan sumber daya dan dana yang serendah-rendahnya (spending well). Indikator efisiensi menggambarkan hubungan antara masukan sumber daya oleh suatu unit organisasi (misalnya: staf, upah, biaya administratif) dan keluaran yang dihasilkan (Mardiasmo, 2009:132). Peraturan Pemerintah No. 71 tahun 2010 menyebutkan bahwa Laporan Realisasi Anggaran (LRA) adalah salah satu komponen laporan keuangan pemerintah yang menyajikan informasi tentang realisasi dan anggaran entitas pelaporan secara tersanding untuk suatu periode tertentu. LRA menyajikan ikhtisar sumber, alokasi, dan pemakaian sumber daya keuangan yang dikelola oleh pemerintah pusat/daerah, yang menggambarkan perbandingan antara anggaran dan realisasinya dalam satu periode pelaporan.

Tujuan pelaporan realisasi anggaran adalah memberikan informasi realisasi dan anggaran entitas pelaporan secara tersanding. Perbandingan antara anggaran dan realisasinya menunjukkan tingkat ketercapaian target-target yang telah disepakati antara legislatif dan eksekutif sesuai dengan peraturan perundang-undangan. Laporan Realisasi Anggaran menyediakan informasi mengenai realisasi pendapatan, belanja, transfer, surplus/defisit, dan pembiayaan dari suatu entitas pelaporan yang masing-masing diperbandingkan dengan anggarannya. LRA juga menyediakan informasi kepada para pengguna laporan keuangan pemerintah tentang indikasi perolehan dan penggunaan sumber daya ekonomi dalam penyelenggaraan fungsi pemerintahan sehingga dapat menilai apakah suatu kegiatan/program telah dilaksanakan secara efisien, efektif, dan hemat sesuai dengan anggarannya (APBN/APBD) serta sesuai dengan peraturan perundang-undangan. Siregar (2015:82) menyatakan bahwa Laporan Realisasi Anggaran adalah laporan menyajikan ikhtisar sumber, alokasi, dan penggunaan sumber daya kas yang dikelola pemerintah dalam suatu periode. Tujuan pelaporan realisasi anggaran adalah memberikan informasi realisasi dan anggaran entitas pelaporan secara tersanding. Perbandingan antara anggaran dan realisasinya menunjukan tingkat ketercapaian target-target yang telah disepakati antara legislatif dan eksekutif sesuai dengan peraturan perundang-undangan. Laporan Realisasi Anggaran menyediakan informasi mengenai realisasi pendapatan, belanja, transfer, surplus/defisit, dan pembiayaan dari suatu entitas pelaporan yang masing-masing diperbandingkan dengan anggarannya. LRA juga menyediakan informasi kepada para pengguna laporan keuangan pemerintah tentang indikasi perolehan dan penggunaan sumber daya ekonomi dalam penyelenggaraan fungsi pemerintahan sehingga dapat menilai apakah suatu kegiatan/program telah dilaksanakan secara efisien, efektif, dan hemat sesuai dengan anggarannya (APBN/APBD) serta sesuai dengan peraturan perundang-undangan. 
Siregar (2015:82) menyatakan bahwa Laporan Realisasi Anggaran adalah laporan yang menyajikan ikhtisar sumber, alokasi, dan penggunaan sumber daya kas yang dikelola pemerintah dalam suatu periode. Laporan Realisasi Anggaran menyajikan informasi meliputi unsur-unsur sebagai berikut:

1. Pendapatan. Pendapatan adalah semua penerimaan rekening kas umum pemerintah yang menambah saldo anggaran lebih dalam periode tahun anggaran yang bersangkutan yang menjadi hak pemerintah dan tidak perlu dibayar kembali oleh pemerintah.

2. Belanja. Belanja adalah semua pengeluaran dari kas umum pemerintah yang mengurangi saldo anggaran lebih dalam periode tahun anggaran yang bersangkutan yang tidak akan diperoleh pembayarannya kembali oleh pemerintah.

3. Transfer. Transfer adalah penerimaan/pengeluaran uang dari/kepada entitas pelaporan lain termasuk dana perimbangan dan dana bagi hasil.

4. Surplus/Defisit. Surplus/Defisit adalah selisih lebih/kurang antara pendapatan LRA dan belanja selama satu periode pelaporan.

5. Pembiayaan. Pembiayaan merupakan setiap penerimaan yang perlu dibayar kembali dan atau pengeluaran yang akan diterima kembali baik pada tahun anggaran bersangkutan maupun tahun-tahun anggaran berikutnya yang dalam penganggaran pemerintah terutama dimaksudkan untuk menutup defisit atau memanfaatkan surplus anggaran.

6. Sisa Lebih/Kurang Pembiayaan Anggaran (SILPA/SIKPA). Selisih lebih kurang antara realisasi anggaran pendapatan dan belanja serta penerimaan dan pengeluaran pembiayaan dalam anggaran selama satu periode.

Penelitian terdahulu. Waney et al. (2018) menunjukan bahwa tingkat atau kriteria efisiensi Dinas Pertanian dan Peternakan Provinsi Sulawesi Utara secara keseluruan sudah diolah dengan baik. Kasakeyan et al. (2020) menunjukan bahwa prosedur pengeluaran kas belanja langsung yang dilaksanakan di Dinas Perindustrian dan Perdagangan Daerah Provinsi Sulawesi Utara pada tahun 2019 sesuai dengan Peraturan Menteri Dalam Negeri Nomor 21 Tahun 2011 tentang Pedoman Pengelolaan Keuangan Daerah.

\section{METODE PENELITIAN}

Jenis data yang digunakan dalam penelitian ini adalah data kualitatif dan kuantitatif. Data yang digunakan dalam penelitian adalah data kualitatif yang berupa hasil wawancara dan data kuantitatif berupa Laporan Realisasi Anggaran (LRA) tahun 2016-2018 pada Sekretariat Daerah Kota Tomohon. Sumber data yang digunakan dalam penelitian ini adalah data primer. Data primer dalam hal ini yaitu data yang diperoleh dari instansi pemerintahan dalam bentuk Laporan Realisasi Anggaran (LRA) serta data yang diambil dari pihak kantor melalui wawancara untuk memperoleh data yang relevan dengan topik ini.

Dalam mendapatkan data yang relevan maka digunakan metode pengumpulan data yang objektif agar pembahasan lebih mendekati dengan keadaan yang sebenarnya. Metode pengumpulan data yang digunakan adalah sebagai berikut: (1) wawancara, dilakukan untuk memperoleh data yang diperlukan dalam penelitian dengan cara mengadakan tanya jawab secara langsung dengan pihak-pihak yang ada dalam instansi terkait untuk mendapatkan data yang relevan dalam hal ini Sekretariat Daerah Kota Tomohon; dan (2) dokumentasi, merupakan metode pengumpulan data yang diperoleh melalui catatan, laporan atau dokumendokumen lainnya yang berkaitan dengan data yang dibutuhkan untuk analisis maupun data lainnya yang berhubungan dengan penelitian. Data yang dikumpulkan melalui tahapan dokumentasi diperoleh dari kantor Sekretariat Daerah Kota Tomohon yang berupa LRA tahun anggaran 2016-2018. 


\section{HASIL PENELITIAN DAN PEMBAHASAN}

\subsection{Hasil penelitian}

Analisis atas pelaksanaan belanja langsung dalam menilai tingkat efisiensi pada Sekretariat Daerah Kota Tomohon didasarkan pada tolak ukur perbandingan realisasi anggaran belanja langsung dengan total anggaran belanja dikalikan 100\%. Rumus tersebut dapat dilakukan analisis tingkat efisiensi belanja langsung yang dilakukan oleh Sekretariat Daerah Kota Tomohon setiap tahunnya sebagai berikut:

$$
\text { Rasio Efisiensi Belanja Langsung }=\frac{\text { Realisasi Anggaran Belanja Langsung }}{\text { Realisasi Total Anggaran Belanja }} \text { X } 100
$$

Pada tahun 2016 rasio tingkat efisiensi pada Sekretariat Derah Kota Tomohon adalah $65.85 \%$, artinya Sekretariat Daerah Kota Tomohon dinilai efisien dalam pengelolaan belanja langsung dimana rasio efisiensinya $>60 \%$. Hal ini berarti bahwa Sekretariat Daerah Kota Tomohon sudah sangat baik dan cermat dalam pengelolaan belanja langsung. Pada tahun 2016 realisasi belanja langsung sebesar Rp. 27.646.194.120 lebih kecil dari pada realisasi anggaran belanja sebesar Rp. 41.980.308.548, dengan demikian dapat dilihat bahwa realisasi anggaran belanja langsung tidak lebih besar dari anggaran yang telah ditetapkan.

Pada tahun 2017 rasio tingkat efisiensi pada Sekretariat Daerah Kota Tomohon adalah $65.42 \%$, artinya Sekretariat Daerah Kota Tomohon dinilai efisien dalam pengelolaan belanja langsung dimana rasio efisiensinya $>60 \%$. Hal ini berarti Sekretariat Daerah Kota Tomohon sudah sangat baik dan cermat dalam pengelolaan anggaran belanja. Pada tahun 2017 realisasi belanja langsung sebesar Rp. 29.161.112.278 lebih kecil dari pada realisasi belanja langsung sebesar Rp. 44.573.502.140, dengan demikian dapat dilihat bahwa realisasi anggaran belanja langsung tidak lebih besar dari anggaran yang telah ditetapkan.

Pada tahun 2018 rasio tingkat efisiensi pada Sekretariat Derah Kota Tomohon adalah $66.73 \%$, artinya Sekretariat Daerah Kota Tomohon dinilai efisien dalam pengelolaan belanja langsung dimana rasio efisiensinya $>60 \%$. Hal ini berarti Sekretariat Daerah Kota Tomohon sudah sangat baik dan cermat dalam pengelolaan anggaran belanja. Pada tahun 2018 realisasi belanja langsung sebesar Rp. 32.013.324.120 lebih kecil dari pada realisasi belanja langsung sebesar Rp. 47.973.178.548, dengan demikian dapat dilihat bahwa realisasi anggaran belanja langsung tidak lebih besar dari anggaran yang telah ditetapkan.

\subsection{Pembahasan}

Tingkat efisiensi belanja langsung Sekretariat Daerah Kota Tomohon pada setiap tahunnya mengalami fluktuasi. Pada tahun 2016 tingkat efisiensi sebesar 65.85\%. Pada tahun 2017, tingkat efisiensinya sebesar 65.42\%, dapat dilihat bahwa pada tahun 2017 mengalami penurunan tingkat efisiensi sebesar $0.43 \%$ tetapi masih dalam kriteria efisien. Pada tahun 2018 kembali terjadi peningkatan tingkat efisiensi sebesar 1,31\% menjadi 66,73\% tetapi masih dalam kriteria efisien. Secara keseluruhan, belanja langsung Sekretariat Daerah Kota Tomohon dari tahun 2016 sampai dengan tahun 2018 sudah efisien dengan tingkat efisiensi dibawah 70\% pada tahun 2016-2018 masuk pada kategori sangat efisien. Dengan demikian dari hasil perhitungan dari tahun ke tahun dapat dikatakan bahwa Sekretariat Daerah Kota Tomohon sudah sangat baik dalam hal pengelolaan anggaran belanja langsung. Hasil perhitungan tingkat efisiensi dari tahun ke tahun berada pada tingkat efisien.

\section{KESIMPULAN DAN SARAN}

\subsection{Kesimpulan}

Berdasarkan hasil pembahasan dapat disimpulkan bahwa tingkat efisiensi Sekretariat

Daerah Kota Tomohon sudah sangat baik. Hal itu dapat terlihat dari hasil pengukuran tingkat efisiensi dari tahun 2016 dengan tingkat efisiensi sebesar 65,85\%, tahun 2017 dengan tingkat 
efisiensi sebesar 65,42\% dan tahun 2018 dengan tingkat efisiensi sebesar 66,73\%. Dari tahun 2016 hingga tahun 2018 secara keseluruhan tingkat efisiensi berada pada kategori efisien, yang artinya Sekretariat Daerah Kota Tomohon sudah sangat baik dalam pengelolaan anggaran yang ada dengan penggunaan anggaran yang minimun untuk hasil yang maksimum.

\subsection{Saran}

Sekretariat Daerah Kota Tomohon dapat mempertahankan kinerja yang baik dalam hal pengelolaan anggaran serta mengevaluasi faktor-faktor lain yang dapat mempengaruhi tingkat efisiensi anggaran agar dapat mempertahankan konsistensi pengelolaan anggaran yang sudah baik. Perlu dilakukan penelitian lanjutan yang berkaitan dengan efisiensi anggaran pada Sekretariat Daerah Kota Tomohon untuk tahun-tahun yang akan datang.

\section{DAFTAR PUSTAKA}

Abdullah, R. (2015). Metodologi penelitian kuantitatif. Yogyakarta: Aswaja Pressindo.

Bastian, I. (2010). Akuntansi sektor publik: Suatu pengantar, Edisi Ketiga. Penerbit Erlangga: Jakarta.

Ekawarna, S. U., Sam, I., \& Rahayu, S. (2009). Pengukuran kinerja Anggaran Pendapatan dan Belanja Daerah (APBD) Pemerintah Daerah Kabupaten Muaro Jambi. Jurnal Cakrawala Akuntansi, 1(1), 49-66. https://scholar.google.co.id/scholar?hl=en\&as_sdt=0,5\&cluster $=65879931534535083$ $\underline{67}$

Erlina, R. (2015). Akuntansi keuangan daerah berbasis akrual. Salemba Empat: Jakarta.

Halim, A. (2016). Akuntansi sektor publik: Akuntansi keuangan daerah. Jakarta: Salemba Empat.

Haruman, T. (2010). Penyusunan anggaran perusahaan. Yogyakarta: Graha Ilmu.

Kasakeyan, B., Karamoy, H., \& Mawikere, L. (2020). Evaluasi sistem dan prosedur pengeluaran kas belanja langsung pada Dinas Perindustrian dan Perdagangan Daerah Provinsi Sulawesi Utara. Going Concern: Jurnal Riset Akuntansi, 15(3), 352-359. https://doi.org/10.32400/gc.15.3.28895.2020

Kontan.ac.id. (2016). Belanja pegawai 294 kabupaten/kota masih tinggi. http://nasional.kontan.co.id/news/belanja-pegawai-294-kabupatenkota-masih-tinggi

Kuncoro, M. (2013). Mudah memahami dan menganalisis indikator ekonomi. Yogyakarta: UPP STIM YKPN.

Mardiasmo. (2009). Akuntansi sektor publik. Yogyakarta: Andy Offset.

Mardiasmo. (2011). Perpajakan, Edisi Revisi. Yogyakarta: Andy Offset.

Nafarin, M. (2013). Penganggaran perusahaan, Edisi Ketiga, Cetakan Kedua, Buku 1. Jakarta: Salemba Empat.

Nordiawan, D. (2009). Akuntansi pemerintahan, Edisi Kesatu. Jakarta: Salemba Empat.

Peraturan Menteri Dalam Negeri Nomor 13 Tahun 2006 tentang Laporan Keuangan Daerah.

Peraturan Menteri Dalam Negeri No. 21 tentang Klasifikasi Belanja.

Peraturan Pemerintah Nomor 71 Tahun 2010 tentang Standar Akuntansi Pemerintah.

Rahayu, K. S. (2013). Konsep dasar dan pedoman pemeriksaan akuntan publik. Yogyakarta: Graha Ilmu.

Ratmono, D. (2015). Akuntansi keuangan daerah berbasis akrual, Cetakan pertama. Yogyakarta: UPP STIM YKPN.

Sadeli, L. M. (2015). Accounting theory, Edisi 5. Jakarta: Salemba Empat.

Sasongko, C., \& Parulian, S. R. (2015). Anggaran. Jakarta: Salemba Empat.

Siregar, S. (2015). Akuntansi sektor publik. Yogyakarta: Sekolah Tinggi Ilmu Manajemen YKPN. 
Stoner, J. A. F. (2010). Principles of management. New Delhi: Phi Beta Kappa.

Suharsimi, A. (2010). Anggaran perusahaan. Jakarta: Rineka Cipta.

Sujarweni, V. W. (2015). Akuntansi sektor publik. Yogyakarta: Pustaka Baru Press.

Undang-Undang Nomor 23 Tahun 2014 tentang Pemerintahan Daerah. Jakarta: Sekretariat Negara.

Waney, C., Saerang, D., \& Alexander, S. (2018). Analisis realisasi anggaran untuk menilai efektivitas dan efisiensi kinerja pemerintah di Dinas Pertanian dan Peternakan Provinsi Sulawesi Utara. Going Concern: Jurnal Riset Akuntansi, 13(02), 334-341. https://doi.org/10.32400/gc.13.02.19527.2018

Wati, E. (2013). Pengaruh budaya organisasi dan komitmen organisasi terhadap hubungan partisipasi penyusunan anggaran dengan kinerja pemerintah daerah (Studi empiris pada Satuan Kerja Perangkat Daerah di Kab. Tanah Datar). Jurnal Akuntansi, 1(2), 124. http://ejournal.unp.ac.id/students/index.php/akt/article/view/620 